\title{
Understanding Education of Maternal Roles Fostered in Floor Wash Ceremony in Lingga, Riau Islands
}

\author{
Meliarika Widyanti Putri ${ }^{1, *}$ Kusnadi $^{2}$ Diany Asritisthia ${ }^{1}$ \\ ${ }^{1}$ Graduate School of Art Education, Yogyakarta State University, Yogyakarta 55281, Indonesia \\ ${ }^{2}$ Faculty of Languages and Arts, Yogyakarta State University, Yogyakarta 55281, Indonesia \\ ${ }^{*}$ Corresponding author.Email: meliarikawidyanti@gmail.com
}

\begin{abstract}
The Floor Wash ritual is a ceremony that includes washing, cleaning the floor. This Floor Wash ritual is held as a mother's pregnancy reaches the seventh month and by paying a down payment to the village midwife who will assist with the labor. The Floor Wash ritual involves purifying the room in which the mother will give birth to the child and this ritual will be held again 44 days after the baby is born. This research employs data collection from the existing literature and secondary documentation, semiotic theory of Pierce, and a descriptive qualitative approach. The Floor Wash ceremony generally fosters maternal roles using symbols.
\end{abstract}

Keywords: Floor Wash Ceremony, Pierce Semiotic Theory, Education of Maternal Roles

\section{INTRODUCTION}

The regency of Lingga in Daik Lingga Region was once the center of the Melayu Kingdom which lasted for about 113 years (1787-1900). This region not only underwent development in terms of Malay customs and culture, but also the spread of Islam. One of the cultures that has been passed from generation to generation and developed is the Malay marriage customs, which also include several post-wedding rituals in events such as pregnancy and childbirth.

Traditional Malay communities often interpret conflicts between natural phenomena and humans in mystical ways. This pattern of thinking results in imagination which results in tales.

The Malay communities in Daik Lingga still believe in the existence of mythical or supernatural creatures. They believe that those creatures also vary such as genies, female ghosts, and bunian people. These supernatural beings also vary in characters, either angelic or evil, so that people in the community would try to make the good spirits their alleys and ward off the evil ones. To maintain harmony in the kingdom of the spirits, there are a number of rituals held in order to prevent evils from doing harm and sending disasters to the community, as seen in the beliefs of Daik Melayu people, that spirits can bring both good and harms.
One of the rituals that are still maintained in the Melayu community is the Floor Wash ceremony, which has been passed on from generation to generation for pregnant women. In this ritual, the pregnant woman must pay some deposit to the village midwife to cleanse the floor of the room where the woman would give birth to the baby after 44 days it is born. The Melayu community believe that without performing this Floor Wash ritual, there would be evils which occupy the floor and disturb the peace of the people around.

This ritual is performed along with prayers for safety to God, wishing safe labor for the mother and the newborn infant.

Based on the discussion above, the writer is interested in presenting the review of the literature on the culture of fostering maternal roles in the Floor Wash ritual through Pierce semiotic theory.

\section{LITERATURE REVIEW}

\subsection{Education}

In the Indonesian dictionary, education is one of the processes in which one's or a group's behavior are matured through teaching and training. There is also a simple view on education, that is an effort to grow and develop their innate potentials both physically and mentally according to the values within the community and culture [1]. 


\subsection{Pierce's Semiotic Theory}

Pierce proposes that signs have triadic relationship that is ground, object and interpretant. In the triadic model, Pierce categorizes signs into the following classifications, namely:

\section{- ground}

Based on the 'ground' there are three further classifications which include: (1) Qualisign. Qualisign is the quality of a sign such as impolite, harsh, and polite words. (2) Sinsign. Sinsign represents the event on the sign, for example, murky water as seen when talking about flood in the river and upstream when talking about heavy rain in the Daik mountain. (3) Legisign. Legisign represent the meaning of norms and value in a sign, for example, in the traffic signs, the sign of a car on a steep road sign, this means that the road ahead is a steep ascent.

\section{- Object [2]}

Based on the object, pierce classifies signs into three groups, namely: (1) Icon. Icon is the sign which relates to their signifying elements which bear similarities to the natural forms such as portraits, maps, and sculptures. (2) Index. Index refers to signs which represent cause and effect relationship in nature, such as smoke which precedes fire. (3) Symbols. Symbols are one of the signs that represents relationship between signs and the signifying elements which are arbitrary, for example Garuda (eagle) symbol of the Republic of Indonesia

\section{- Interpretant}

Pierce groups interpretant into three categories, namely: (1) Rheme. Rheme is one of the possible signs based on choice, for example, a person whose eyes are red seems to have cried, have some eye disease or some bug irritation, have just woken up or look sleepy. (2) Dicent sign or Dicisign. Dicent sign or Dicisign refers to one of the signs which represent exactly what has happened, for example in an evening, a road sign of accident is put after traffic accidents occur frequently. (3) Argument. Argument indicates signs which give explanation on an event or object [3].

\section{RESEARCH METHOD}

This research employs a qualitative method to reveal meanings and understand a problem based on qualitative data [4]. Charles Pierce's semiotic theory is used here to reveal the meaning of the symbols and signs in the Floor Wash ceremony. According to Pierce, symbols are forms of arbitrary and conventional signs based on agreement or convention among a number of people or society. Symbols can take forms of spoken language, actions, or object with visual forms. The writer also used primary and secondary data. The primary data were obtained by observing the Floor Wash ceremony and the secondary data were obtained from books, articles, and journals.

\section{DISCUSSION}

\subsection{Floor Wash Ceremony}

The Floor Wash ceremony is another term for washing, cleaning the floor. This tradition has been held for generations especially the community in Daik, Lingga Regency. This ceremony is aimed at purifying the souls and bodies of the family. By performing this ceremony, the family will be protected from misfortunes caused by the energy of the spirits that they believe to exist. This ceremony involves relatives, neighbors, community leaders, religious leaders and invited guests. A family will perform this ritual in the seventh month of pregnancy by paying a down payment to the midwife who will assist in delivering the newborn baby. The Floor Wash tradition is performed in the room in which the mother will deliver the baby and then it will be performed again after 44 days of its birth and completed by giving the midwife salt and tamarind as an expression of gratitude from the family.

\subsection{Materials and Equipment for Floor Wash Ceremony}

The materials and tools for Floor Wash Ceremony include:

1. 2 whole coconuts

2. a bowl of rice seeds

3. a bowl of raw rice

4. 2 candles

5. Traditional talcum powder/ perfume

6. eyeliner

7. a comb

8. a plate of yellow sticky rice

9. tamarinds and salt

10. a hen (for a baby girl) and a rooster (for a baby boy)

11. A metal tray

12. 'tukal' or coarse yarn

13. a kaffir lime

14. a mirror

Before the ritual is performed, the materials are arranged based on the order of the ceremony. The coconut fruits should be cut into an oval form, and then put on the metal tray containing rice seeds. On the right and left sides of the coconut, two candles are fastened on the sides. After all of the materials are arranged in an order, the mother and infant who have dressed accordingly together with the midwife will perform the traditional ceremony. 


\subsection{Steps in Floor Wash Ceremony}

Similar to other Indonesian traditional ceremonies, the village midwife would recite the mantras and then spatter to the right and left sides, and she would also take the chicken by its head and make its feet scratch the ground forwards and backwards and to the left and right sides for seven times. After that, she would push her thumb into the chicken's mouth and press it on the chicken palate. Then she would press the baby's forehead three times, from the top to the right and from the top to the middle and from the top to the left. After all of these are performed in order, the floor of the room where the mother has delivered the baby is washed. The coconuts are laid on the floor and turned to right and left sides then laid forward, and then the coconuts are shaken near the right ear of the baby. After that, the midwife would apply some talcum powder which is mixed with kaffir lime juice, then the mixture is poured on to the floor evenly and the floor is scrubbed and washed with clean water. Some oiling, combing and application of eyeliner are then performed and before that the midwife has already put some perfume on herself. After decorating, the midwife would sit before the tray containing a mirror, coconuts, and candles on the floor.

\subsection{Education of Maternal Roles as seen through Pierce Semiotic Theory of Signs}

The meaning of the symbols from the materials and equipment in Floor Wash Ceremony are explained as follows: (1) Chicken. The chicken either a rooster for a baby boy or a hen for a baby girl, represents blood that is shed so that evil spirits on the ground would not disturb or tempt the baby. If the baby keeps crying, it may have been disturbed by an evil spirit (jembalang) because there are certain conditions that have not been met or there have been some missing steps or materials when performing the Floor Wash ceremony. (2) Rice seeds. Rice symbolizes vigor or a symbol for males, and raw rice symbolizes females. Rice seeds and raw rice represent the fortune for the family. (3) Yarn. It is believed that thread represents obstacles, because as a creature, a human being would face obstacles. In the ceremony, the thread is cut so that the baby can overcome and deal with unfavorable situations in life. (4) Candles. Candles symbolize light in darkness. This is meant to ensure that the child is always guided by God and has faith in life. (5) Coconuts, coconuts are the symbol of life, as its buds can thrive in many places, and the coconuts here represent the child to thrive and adapt to his or her environment. When the midwife shakes the coconuts and its splashing sound inside is loud enough to hear, then the baby will be a good child and vice versa. (6) The mirror, comb and eyeliner are the items which symbolizes cleanliness, and neatness which will influence someone's health. (7) The traditional talcum powder or the perfume of 'langi' is made by mashing gambier (white catechu), tamarinds, chalk, and lime. This powder is used as a potion to cleanse and purify oneself so that he or she is protected from evil spirit and to repel misfortunes. (8) 'Pulut' (yellow sticky rice). This represents male and 'surabi' (traditional pancakes) represent females.

\section{CONCLUSION}

This Floor Wash ceremony especially in Daik, Lingga regency has been passed on for generations. The ceremony is performed so that the host family is protected from dangers caused by evil spirits they believe to exist. Based on Pierce's semiotic theory, it can be concluded that educating the mother about maternal roles is meant to create a safe and prosperous life for the child, who is expected to observe the traditional values and norms and be pious to the Almighty Allah.

\section{REFERENCES}

[1] Ihsan, Fuad. Dasar-Dasar Kependidikan [Education Basics]. Jakarta: Rineka Cipta, 2005. p. 1.

[2] Gogali, Venessa Agusta. Industri Media Dalam Budaya Popular Kajian Semiotika Pierce Pada Drama Korea Saranghae, I Love You [Media Industry in Popular Culture Studying Pierce's Semiotics in Korean Drama Saranghae, I Love You]. Jurnal Komunikasi 7(1), 2016. p. 35. URL: https://ejournal.bsi.ac.id/ejurnal/index.php/jkom/art icle/view/2173

[3] Nazaruddin, Kahfie. Pengantar Semiotika [Introduction to Semiotics]. Yogyakarta: Graha Ilmu, 2015.

[4] Yusuf, A. Muri. Metode Penelitian: Kuantitatif, Kualitatif, dan Penelitian Gabungan [Research Methods: Quantitative, Qualitative, and Combined Research]. Jakarta: Kencana, 2014. p. 43. 